\title{
EFFECTS OF HEAT-KILLED PROBIOTIC COMPLEX ON ACUTE DIARRHOEA IN CHILDREN
}

\author{
Reza Gunadi Ranuh ${ }^{1}$, Alpha Fardah Athiyyah ${ }^{1}$, Andy Darma ${ }^{1}$, Bony Pramono ${ }^{1}$, Laksmi Suci \\ Handini $^{1}$, Maria Christina Shanty ${ }^{1}$, Subijanto Marto Sudarmo ${ }^{1}$ \\ ${ }^{I}$ Department of Child Health, Dr Soetomo Hospital, Faculty of Medicine, Airlangga University, Surabaya, Indonesia \\ *rezagunadi@gmail.com \\ https://doi.org/10.34302/crpifst/2019.11.5.7 \\ Article history: \\ Received: \\ 9 March 2019 \\ Accepted: \\ 20 September 2019 \\ Keywords: \\ Probiotics \\ Heat-killed probiotics \\ Duration of illness \\ Stool frequency \\ Stool consistency

\begin{abstract}
Probiotics are known in paediatrics as a new alternative treatment for diarrhoea. Some studies have found that a heat-killed probiotic complex (HKPC) has the same potential effects as active probiotics on diarrhoea in children. However, there is little research on this subject. We conducted a study to examine the HKPC effect on duration of illness and degree of recovery from acute diarrhoea in 6-24-month-old children. This study is a randomised, double-blind, controlled clinical trial with children aged 6-24 months with acute diarrhoea. The children were divided into two groups: one received HKPC and the other placebo. Stool samples were collected prior to treatment to determine the presence of rotavirus and the evidence of fat and/or lactose malabsorption. All the children were observed regarding the duration of diarrhoea, stool frequency, and stool consistency until they recovered. A total of 98 children met the selection criteria. Rotavirus was found in more than half of the stool samples (53\%). Fat malabsorption was present in $46 \%$ of the samples, yet lactose malabsorption was detected in only $8 \%$ of the samples. The HKPC group had a shorter recovery time (3 days) than the placebo group (4 days), which is not statistically different $(p=0.100)$. There were no significant differences in recovery levels from the first day until the last day of observation $(p=0.487)$. According to the result, administration of HKPC has no significant effect on duration of illness and
\end{abstract} \\ level of recovery in 6-24-month-old children with acute diarrhoea.
}

\section{Introduction}

Diarrhoea is the main cause of child morbidity in developing countries. The mortality rate of diarrhoea in children is 1.4 million per year globally, with the highest prevalence in developing countries such as India, Nigeria, Congo, Pakistan, and China (Black et al., 2010). The incidence rate of diarrhoea is high in children under the age of 2 , with the peak rate in children aged 6-24 months who start to eat other foods and reduce breast milk intake (Soeparto et al., 1999; Ansari et al., 2012). The most common causes of diarrhoea associated with high mortality are rotavirus, followed by Cryptosporidium spp and Shigella spp (Troeger et al., 2017). Cohort studies have shown that nearly all children suffer at least one rotavirus infection before the age of 5, independent of their socioeconomic status (WHO, 2009). Acute diarrhoea caused by infection can reduce lactose absorption. It damages the small intestinal mucosa and decreases the lactase enzyme, which leads to decreased lactose absorption. This, along with decreased fat absorption, leads to increased lactose and fat in the stool (Khani et al., 2012).

Probiotics are known in paediatrics as a new alternative treatment for diarrhoea, due to their beneficial functions in the gastrointestinal tract. 
They produce bacteriocin, which acts as a competitive inhibitor, decreasing the bacterial growth and strengthening the tight junctions in the brush border. Some studies have shown that probiotics could favour the recovery phase in virus-associated diarrhoea by enhancing pathogen-specific secretory IgA production and inhibiting viral multiplication (Ohland and MacNaughton, 2010).

A heat-killed probiotic complex (HKPC) is a preparation with inactive probiotic bacteria or killed probiotics. It is more stable in heat and prolonged storage. Though it is inactive, the complex still contains bacteriocin, lactase, and the deoxyribonucleic acid (DNA) of the probiotic bacteria. These have the function of decreasing inflammation and stopping cell necrosis. It has been stated that HKPCs have the same beneficial potential as living probiotics (Ng et al., 2009). A study by Supriatmo (2006) demonstrated that HKPCs are better than living probiotics at shortening the duration of diarrhoea in children.

In this study, we examined the effect of HKPC on the duration of illness and the degree of recovery from acute diarrhoea in 6-24month-old children.

\section{Materials and methods}

\subsection{Materials}

\subsubsection{Samples}

All 6-24-month-old children with acute diarrhoea (described as watery diarrhoea occurring more than 3 times per day, for less than 3 days before hospitalisation) in the Child Health Department of Dr Soetomo Hospital from April 2008 to August 2008 were included in this study. Children with a history of probiotic, antibiotic, or zinc administration prior to hospitalisation and with severe comorbidities or malnutrition were excluded from this study. The study design described in figure 1 .

The duration of illness was determined by the mean duration of diarrhoea in days after being hospitalised until recovery. Recovery level was determined based on frequency of defecation and consistency of stool, and was classified as the following:

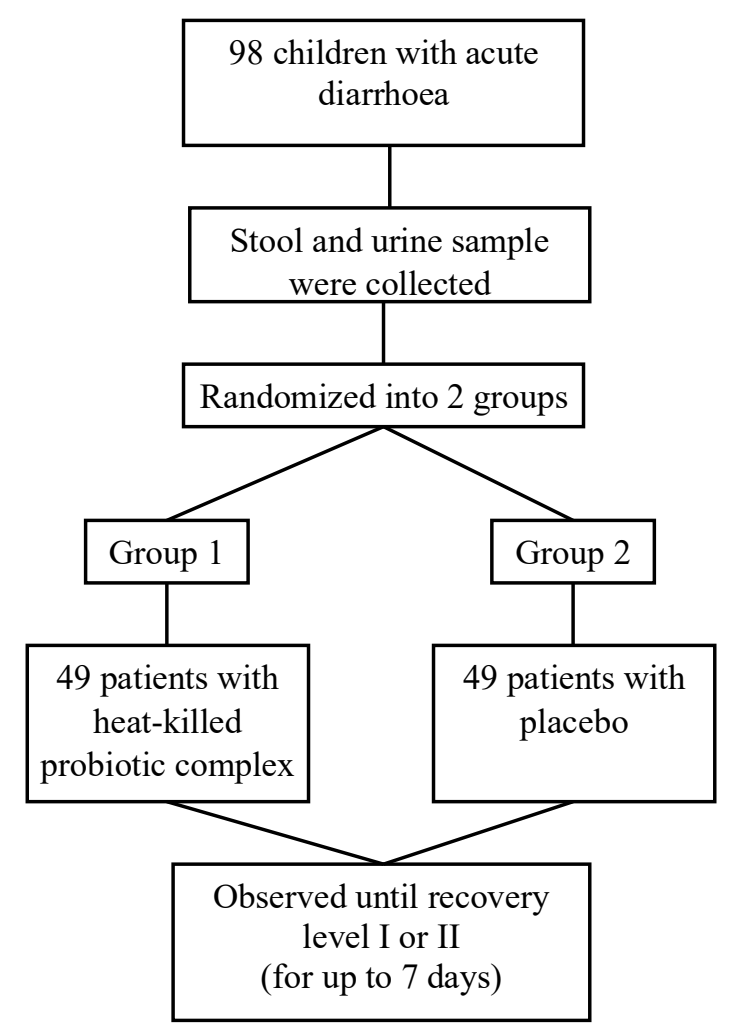

Figure 1. Subject treatment

(1) recovery level I: solid stool consistency no more than 3 times per day; (2) recovery level II: mushy stool consistency no more than 3 times per day; (3) recovery level III: watery stools with lumps no more than 3 times per day; (4) no recovery: watery diarrhoea more than 3 times per day until the seventh day of diarrhoea with standardised treatment. Stool consistency was observed according to the Bristol stool chart.

\subsubsection{Heat-Killed Probiotic Complex}

In this study, we used a manufactured heatkilled probiotic complex (Dialac $\left.{ }^{\circledR}\right)$ with tyndallized lyophilisate of Lactobacillus acidophilus as an inactive probiotic at a dose of $3 \times 10^{10} \mathrm{CFU} /$ day. This HKPC also contains bacteriocin, lactase enzyme, bacterial CpGDNA, vitamins B2, B3, B6 and $\mathrm{C}$, thiamine, zinc, calcium, sweetener and fruit flavouring. The product is packaged in sachets with a net weight of 1 gram. The control group received a similar sachet, but it contained only $300 \mathrm{mg}$ of Saccharum lactis (placebo). 


\subsection{Methods}

The Ethical Research Commission of Dr Soetomo General Hospital in Surabaya approved this study. This study is a randomised, double-blind, controlled clinical trial in which randomisation was done by a third party. Each child meeting the selection criteria was examined and a stool sample was collected for laboratory analysis. The children were then randomised into two groups: an HKPC group and a control group. They received standard treatment for diarrhoea and were given a sachet of HKPC or placebo twice a day until they reached recovery level I or II. All the patients were evaluated every day in terms of defecation frequency and faecal consistency for up to 7 days until they reached recovery level I or II.

The stool and urine examination was done only once before the HKPC or placebo administration. The urine samples were collected using the sterile urine collector for at least $5 \mathrm{ml}$. The stool samples were collected using a sterile pot. Approximately 5 grams of stool sample, taken from the middle part of the stool, was sent inside the sterile pot to the laboratory for the examinations within 3 hours. A rotavirus kit (Meridian Bioscience, ImmunoCard STAT! ${ }^{\circledR}$ Rotavirus Devices 750030, USA) was used to detect rotavirus antigen in the stool using the qualitative immunochromatic assay method. Approximately $0.25 \mu \mathrm{L}$ (if liquid or semi-solid) or $2 \mathrm{~mm}^{3}$ (if solid) of the stool sample was diluted with $350 \mu \mathrm{L}$ of sample diluent (a buffer containing $0.1 \%$ sodium azide) in a $12 \times 75 \mathrm{~mm}$ glass test-tube and homogenised with vortex mixer (QL System, MX-2500 Vortex Mixer, $\mathrm{UK}$ ) for ten seconds. The diluted sample (as much as $150 \mu \mathrm{L}$ ) was transferred to the sample port then incubated for ten minutes at room temperature $\left(25\right.$ to $\left.27^{\circ} \mathrm{C}\right)$. The result was obtained by visually reading the control and test zones for the presence or absence of a line at the end of the incubation period. The test result was positive if the test and control lines were both visually detectable.

Every stool sample was also analysed using the Clinitest ${ }^{\mathbb{R}}$ tablet (Bayer HealthCare, Mexico) to detect any lactose malabsorption by detecting unabsorbed sugars in the stool. Approximately 2 grams of the stool was diluted with twice its volume of distilled water (RPI, Distilled Water W20525, USA) in a 12x100 mm glass test-tube, then mixed with a vortex mixer. Fifteen drops of this mixture were transferred to a test-tube, a Clinitest tablet was added, then boiled and wait for 15 seconds after boiling. The result was observed at the end of 15 seconds and compared to the Clinitest ${ }^{\circledR}$ colour chart. The amount of reducing substance present was rated as $0 \%$, $0.25 \%, 0.5 \%, 0.75 \%, 1 \%$, or $2 \%$. A result of $0.5 \%$ or more indicated the presence of an abnormal amount of sugar in the stool.

For every stool sample, the floating test was done to detect any fat malabsorption. 3 grams of the stool sample was gently placed in a $100 \mathrm{~mL}$ glass flask containing $30 \mathrm{~mL}$ of distilled water (RPI, Distilled Water W20525, USA) at room temperature $\left(25\right.$ to $\left.27^{\circ} \mathrm{C}\right)$, and its floating or sinking position was observed within 30 seconds. If the stool floated, it indicated the presence of steatorrhoea.

Both the stool and urine samples were examined for bacterial identification. The urine and stool samples were cultured in MacConkey agar (Merck Millipore, MacCONKEY Agar 105465 , Germany) for 18-24 hours to isolate the bacteria colony. Gram staining was done to confirm and choose the right panel for bacteria identification. The colony then suspended into the Phoenix ${ }^{\mathrm{TM}}$ ID broth (BD Diagnostic, Phoenix $^{\text {TM }}$ ID broth 246001, USA) with inoculum density 0,5 McFarland (BD Diagnostic, BD PhoenixSpec ${ }^{\mathrm{TM}}$ nephelometer 440910, USA). The bacteria identification was using BD Phoenix ${ }^{\mathrm{TM}}$ Automated Microbiology System (BD Diagnostic, Phoenix ${ }^{\mathrm{TM}} 100$ instruments 448100, USA) with the panel for gram positive bacteria is PMIC/ID-55 and gram negative bacteria is NMIC/ID-4.

The collected data was analysed statistically using SPSS Windows Release 12.00 software. Descriptive analysis was carried out to compare the duration of illness, frequency of defecation, stool consistency, and recovery levels between the two groups. Lactose and fat malabsorption 
tests and the rotavirus test were carried out for the sample median, modus, and proportion. The differences between the two groups were analysed using Chi Square for normally distributed variables and the Mann-Whitney U test for non-normally distributed variables.

\section{Results and discussions}

A total of 98 eligible patients were included in the study. They were divided randomly into equally sized HKPC and control groups (49 patients each). None of the patients met the exclusion criteria or withdrew from the study. The average age of the selected patients were 11 months old, with almost equal proportions of males $(53 \%)$ and females $(46 \%)$. The nutritional status of all the patients in this study was predominantly mild malnutrition $(47 \%)$. The baseline data is shown in Table 1.

Table 1. Baseline data

\begin{tabular}{|c|c|c|}
\hline & $\begin{array}{c}\text { HKPC group } \\
(\%)\end{array}$ & $\begin{array}{c}\text { Control } \\
\text { group }(\%)\end{array}$ \\
\hline Age (median) & 11 & 11 \\
\hline \multicolumn{3}{|l|}{ Gender } \\
\hline Male & $26(53 \%)$ & $27(55 \%)$ \\
\hline Female & $23(47 \%)$ & $22(45 \%)$ \\
\hline \multicolumn{3}{|l|}{$\begin{array}{l}\text { Nutritional } \\
\text { status }\end{array}$} \\
\hline Overweight & $6(28 \%)$ & $6(4 \%)$ \\
\hline Normal & $24(49 \%)$ & $16(33 \%)$ \\
\hline $\begin{array}{l}\text { Mild } \\
\text { malnutrition }\end{array}$ & $19(39 \%)$ & $27(55 \%)$ \\
\hline \multicolumn{3}{|l|}{$\begin{array}{l}\text { Dehydration } \\
\text { states }\end{array}$} \\
\hline $\begin{array}{l}\text { Without } \\
\text { dehydration }\end{array}$ & $1(2 \%)$ & $1(2 \%)$ \\
\hline $\begin{array}{l}\text { Mild } \\
\text { dehydration }\end{array}$ & $9(18 \%)$ & $9(18 \%)$ \\
\hline $\begin{array}{l}\text { Moderate } \\
\text { dehydration }\end{array}$ & $39(80 \%)$ & $39(80 \%)$ \\
\hline \multicolumn{3}{|l|}{ Breast feeding } \\
\hline $\begin{array}{l}\text { Receive breast } \\
\text { feeding }\end{array}$ & $28(57 \%)$ & $26(53 \%)$ \\
\hline $\begin{array}{l}\text { Not breast } \\
\text { feeding }\end{array}$ & $21(43 \%)$ & $23(47 \%)$ \\
\hline
\end{tabular}

The history of diarrhoea prior to hospitalisation is shown at table 2. In this study, most children with diarrhoea were hospitalised after one-day period of diarrhoea with approximately 6 times diarrhoea per day. More than half of the total children had at least once diarrhoea episode within the last 3 months (73\% for both HKPC and control group). The feature of diarrhoea mostly watery with lumpy stool (55\% for HKPC group and $65 \%$ for control group), none are followed with blood and mucus (78\% for HKPC group and $71 \%$ for control group), and other symptoms that followed are vomiting, fever and flu-like syndrome.

Table 2. Clinical characteristic

\begin{tabular}{|c|c|c|}
\hline & HKPC group & $\begin{array}{l}\text { Control } \\
\text { group }\end{array}$ \\
\hline $\begin{array}{l}\text { Mode duration of } \\
\text { diarrhoea (range) }\end{array}$ & $1(1-3)$ & $1(0-3)$ \\
\hline $\begin{array}{l}\text { Mode frequency of } \\
\text { diarrhoea }\end{array}$ & $6(2-11)$ & $6(1-20)$ \\
\hline \multicolumn{3}{|l|}{ Diarrhoea consistency } \\
\hline Entirely liquid & $10(20 \%)$ & $13(27 \%)$ \\
\hline $\begin{array}{l}\text { Watery with lumpy } \\
\text { stool }\end{array}$ & $27(55 \%)$ & $32(65 \%)$ \\
\hline Mushy stool & $1(2 \%)$ & 0 \\
\hline \multicolumn{3}{|l|}{$\begin{array}{l}\text { Diarrhoea } \\
\text { characteristic }\end{array}$} \\
\hline Precense of mucus & $10(20 \%)$ & $13(27 \%)$ \\
\hline $\begin{array}{l}\text { Precense of blood } \\
\text { and mucus }\end{array}$ & $1(2 \%)$ & $1(2 \%)$ \\
\hline No blood and mucus & $38(78 \%)$ & $35(71 \%)$ \\
\hline \multicolumn{3}{|l|}{ Comorbidities } \\
\hline Vomitting (n) & 41 & 36 \\
\hline $\begin{array}{l}\text { Flu-like syndrome } \\
\text { (n) }\end{array}$ & 28 & 36 \\
\hline Fever (n) & 28 & 27 \\
\hline Convulsion (n) & 0 & 0 \\
\hline \multicolumn{3}{|l|}{$\begin{array}{l}\text { Episode of diarrhoea } \\
\text { in the last } 3 \text { months } \\
\end{array}$} \\
\hline One time & $36(73 \%)$ & $36(73 \%)$ \\
\hline Two times & $7(14 \%)$ & $7(14 \%)$ \\
\hline Three times & $2(5 \%)$ & $5(10 \%)$ \\
\hline Four times & $4(8 \%)$ & $1(3 \%)$ \\
\hline
\end{tabular}

Data from the stool examination (Table 3) shows that rotavirus was found in more than half of the total samples (53\%). This is consistent with the study of Sudarmo et al. (2015), which found rotavirus in $80.7 \%$ of children aged 6-24 months with diarrhoea. An observation conducted in Jakarta showed that rotavirus prevalence was high among hospitalised children aged 6-23 months with acute diarrhoea, 
and it was even more prevalent in the dry season (Soenarto et al., 2009).

Table 3. Stool examinations data

\begin{tabular}{|c|c|c|}
\hline & HKPC group & $\begin{array}{c}\text { Control } \\
\text { group }\end{array}$ \\
\hline Rotavirus test & $23(47 \%)$ & $29(59 \%)$ \\
\hline Positive & $26(53 \%)$ & $20(41 \%)$ \\
\hline Negative & & \\
\hline $\begin{array}{l}\text { Lactose } \\
\text { malabsorption }\end{array}$ & $46(94 \%)$ & $44(90 \%)$ \\
\hline Positive & $3(6 \%)$ & $5(10 \%)$ \\
\hline Negative & & \\
\hline $\begin{array}{l}\text { Fat } \\
\text { malabsorption }\end{array}$ & $26(53 \%)$ & $27(55 \%)$ \\
\hline Positive & $23(6 \%)$ & $22(45 \%)$ \\
\hline Negative & &
\end{tabular}

Fat malabsorption in acute diarrhoea is more prevalent than lactose malabsorption (46\% vs. $8 \%$ ). Although uncommon in this study, in research done by Nyeko et al. (2010), 68\% of 312-month-old malnourished children with acute diarrhoea displayed lactose malabsorption. This malabsorption is caused by decreased intraluminal digestion due to a reduced absorptive surface area and disturbed enterocyte metabolism. The undigested fat substrate is then hydrolysed by the normal flora in the colon into free fatty acids (Thapar and Sanderson, 2004).

Table 4. Result of the urine and stool culture

\begin{tabular}{|l|c|c|}
\hline & $\begin{array}{c}\text { HKPC group } \\
\text { (\%) }\end{array}$ & $\begin{array}{c}\text { Control } \\
\text { group (\%) }\end{array}$ \\
\hline Urine culture & $32(65 \%)$ & $27(55 \%)$ \\
\hline No bacterial growth & $13(27 \%)$ & $17(35 \%)$ \\
\hline E. colli & $1(2 \%)$ & 0 \\
\hline Proteus & $2(4 \%)$ & $2(4 \%)$ \\
\hline $\begin{array}{l}\text { Klebsiella } \\
\text { pneumoniae }\end{array}$ & $1(2 \%)$ & $1(2 \%)$ \\
\hline Klebsiella oxytoca & 0 & $2(4 \%)$ \\
\hline Enterobacteriaceae & & \\
\hline Stool culture & $45(92 \%)$ & $46(94 \%)$ \\
\hline No bacterial growth & 0 & $1(2 \%)$ \\
\hline Pathogenic E. colli & $4(8 \%)$ & $2(4 \%)$ \\
\hline Klebsiella pneumonia & &
\end{tabular}

The table 4 shows the result of urine and stool culture. From the urine culture, although mostly for both the two groups found no bacterial growth (65\% for HKPC group and 55\% for control group), but E. colli found in $27 \%$ HKPC group and 35\% in control group. In this study, the stool culture result showed that it is less likely to had bacterial co-infection in children acute diarrhoea (92\% for HKPC group and $94 \%$ for control group).

\subsection{Duration of illness}

Between the two groups, the control group needed a longer time to recover (4 days) than the HKPC group (3 days) with range duration for HKPC group is 2-8 days and for control group 2-7 days, but this was not statistically different $(p=0.100)$. A similar result was found in another study, which compared the effects of HKPC and active probiotics administration on the duration of illness in children with acute diarrhoea (Indriyani, Juffrie and Setyati, 2016).

Previous studies, in which a higher dosage of heat-killed probiotics than live probiotics was administered to treat acute diarrhoea, found that heat-killed probiotics reduced the duration of acute watery diarrhoea and shortened the length of hospitalisation (Applegate et al., 2013; Supriatmo, 2006). This result showed that HKPCs are as beneficial as live probiotics because they have developed an ability to adhere to the mucus of the human intestine and inhibit the process of diarrheal infection (Supriatmo, 2006).

\subsection{Level of Recovery}

The recovery level data is shown in Table 5 . There were no significant differences in recovery levels between the HKPC and control groups from the first day until the last day of observation $(p=0.487)$. This result shows that heat-killed probiotics failed to improve the level of recovery in treating acute diarrhoea in 6-24month-old children. 
Table 5. Recovery level between the HKPC group and control group

\begin{tabular}{|l|c|c|c|}
\hline & HKPC group & Control group & \multirow{2}{*}{ value } \\
\hline Recovery level I & 12 & 12 & \multirow{2}{*}{0.487} \\
\hline Recovery level II & 31 & 43 & \\
\hline
\end{tabular}

Many clinical trials on probiotics have also focussed on reduced severity in addition to level of recovery. Severity was represented as stool frequency a few days after administration of probiotics (Applegate et al., 2013). Supriatmo (2006) found that heat-killed probiotics did shorten the duration, but not the stool frequency, of acute diarrhoea in children. Previous studies by Hatta et al. (2011) have assessed recovery levels based on the frequency (times/day) and duration of diarrhoea (hours). They found it difficult to assess stool consistency, and this could introduce bias (Hatta et al., 2011). However, in this study, we used the Bristol stool chart to prevent a biased stool consistency assessment.

There are only a few studies of recovery levels based on stool frequency and consistency. Further studies are needed on recovery levels for HKPC administration in acute diarrhoea.

\section{Conclusions}

Administration of HKPC does not make any significant difference on the duration of illness or recovery levels in 6-24-month-old children with acute diarrhoea, whether or not associated with rotavirus or malabsorption.

\section{References}

Ansari, S. et al. (2012). Characterisation of rotavirus causing acute diarrhoea in children in Kathmandu, Nepal, showing the dominance of serotype G12. Journal of Medical Microbiology. 62(Pt 1), 114-120. doi: 10.1099/jmm.0.048124-0

Applegate, J. A. et al. (2013). Systematic review of probiotics for the treatment of community-acquired acute diarrhoea in children. BMC Public Health. 13(3), S16. doi: 10.1186/1471-2458-13-S3-S16.

Black, R. E. et al. (2010). Global, regional, and national causes of child mortality in 2008: a systematic analysis. The Lancet. 375(9730),

\section{9-87. doi: 10.1016/S0140- 6736(10)60549-1.}

Hatta, M. et al. (2011). Comparison of zincprobiotic combination therapy to zinc therapy alone in reducing the severity of acute diarrhoea. Paediatrica Indonesiana. 51(1), 1-6. doi: 10.14238/pi51.1.2011.1-6.

Indriyani, A., Juffrie, M., Setyati, A. (2016). Effects of live versus heat-killed probiotics on acute diarrhoea in young children. Paediatrica Indonesiana. 52(5), 249-54. doi: 10.14238/pi52.5.2012.249-54.

Khani, S. et al. (2012). Probiotics as an alternative strategy for prevention and treatment of human diseases: a review. Inflammation \& Allergy-Drug Targets. 11(2), 79-89. doi: $10.2174 / 187152812800392832$.

$\mathrm{Ng}$, S. C. et al. (2009). Mechanisms of action of probiotics: recent advances. Inflammatory Bowel Diseases. 15(2), 300-10. doi: 10.1002/ibd.20602.

Nyeko, R., Kalyesubula, I., Mworozi, E. and Bachou, H. (2010). Lactose intolerance among severely malnourished children with diarrhoea admitted to the nutrition unit, Mulago hospital, Uganda. BMC Pediatrics. 10(1), 31. doi: 10.1186/1471-2431-10-31.

Ohland, C. L., MacNaughton, W. K. (2010). Probiotic bacteria and intestinal epithelial barrier function. American Journal of Physiology-Gastrointestinal and Liver Physiology. 298(6), 807-19. doi: 10.1152/ajpgi.00243.2009.

Soenarto, Y. et al. (2009). Burden of severe rotavirus diarrhoea in Indonesia. The Journal of Infectious Diseases. 200(s1), 188-94. doi: 10.1086/605338.

Soeparto, P., Djupri, L. S., Sudarmo, S. M., Ranuh, R. G. (1999). Sindroma diare (2nd ed.). Surabaya: Gramik FK Universitas Airlangga.

Sudarmo, S.M., Shigemura, K., Athiyyah, A., 
Osawa, K., Wardana, O., Darma, A., Ranuh, R., Shirakawa, T. (2015). Genotyping and clinical factors in paediatric diarrhea caused by rotaviruses: one-year surveillance in Surabaya, Indonesia. Gut Pathogens. 7(1), 3. doi:10.1186/s13099-015-0048-2.

Supriatmo, S. (2006). Effectivity of live versus heat-killed probiotic in children with acute diarrhoea. Majalah Kedokteran Nusantara. 39(4), 419-23.

Thapar, N., Sanderson., I. R. (2004). Diarrhoea in children: an interface between developing and developed countries. The Lancet. 363, 641-53.

Troeger, C. et al. (2017). Estimates of global, regional, and national morbidity, mortality, and aetiologies of diarrhoeal diseases: a systematic analysis for the Global Burden of Disease Study 2015. The Lancet. 17(9), 909-48. doi: 10.1016/S14733099(17)30276-1.

World Health Organisation. (2009). Estimated rotavirus deaths for children under 5 years of age: $2004 \quad$ update 2009. http://www.who.int/immunization_monitori ng/burden/rotavirus_estimates/en/index.htm 1 [accessed February $\left.6^{\text {th }}, 2010\right]$.

\section{Acknowledgment}

The authors would like to thank to all the teams who worked on this study. 